See discussions, stats, and author profiles for this publication at: https://www.researchgate.net/publication/345985324

\title{
Capitalism leading to unhealthy food consumption
}

Article in Strategic Change · November 2020

DOI: 10.1002/sc.2379

CITATIONS

0

2 authors:

Rajibul Hasan

National University of Ireland, Maynooth

65 PUBLICATIONS 271 CITATIONS

SEE PROFILE
READS

692

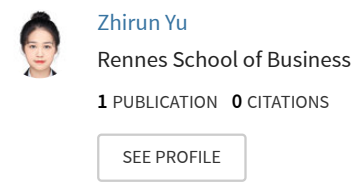

Some of the authors of this publication are also working on these related projects:

Project Computers in Human Behavior View project

Towards an Integrated Theory of Pro-Poor Innovation Adoption in the BOP. View project 


\title{
Capitalism leading to unhealthy food consumption ${ }^{1}$
}

\author{
Rajibul Hasan
}

Maynooth University, Ireland.

\section{Zhirun YU}

Rennes School of Business, France.

\section{Correspondence:}

Rajibul Hasan

Maynooth University, Ireland.

Email: rajibul.hasan@mu.ie

Cite as: Hasan, R., \& YU, Z. (2020). Capitalism leading to unhealthy food consumption. Strategic Change, 29(6), 633-643.

\begin{abstract}
How fast-food and beverage companies, which are driven by capitalism, adopt the ethical product, price, promotion, and place strategies to influence consumers' perceived value and purchase intentions. Results from hypotheses testing show the ethical aspects of fast-food and beverage companies' marketing strategies highly influence consumers' perceived value of products and further prove perceived value positively influences consumers' purchase intentions. These findings will educate fast-food and carbonated beverage companies on the ethical problems of marketing unhealthy foods. Our results also lead to fast-food and carbonated beverage companies to reconsider their marketing strategies for the improvement of this serious situation that can be tied to capitalism.
\end{abstract}

\section{Introduction}

Capitalism is considered the leading cause of the growing number of environmental and unhealthy food consumption problems. Though it seems that there is not a univocal definition of capitalism throughout the history, its influences on institutional transformation have led to an economy where a few very competitive companies dominate key industries that affect our daily lives (Tepper, 2018). For example, the development of technology has led to daily marketing communications barraging consumers in different forms, making it harder for consumers to assess and control the influence large firms' marketing tactics, which focus on

\footnotetext{
${ }^{1}$ JEL Classification Codes : P1, M31, P45.
} 
maximizing profits, exert on them (Sprott, 2008). Because capitalist values are embedded in our way of life, such market advertising may detrimentally affect our capitalism-steeped society and consumers' well-being (Cunningham, 2003).

Expanding globalization has resulted in significant cultural and sociological changes that have influenced consumers' eating habits and nutritional preferences (Izquierdo-Yusta et al., 2018). Today's consumers are concerned about not only the safety of their food but also its health impact (Izquierdo-Yusta et al., 2018). Consequently, as more people focus on consumer health and food quality and advocate for socially responsible initiatives, the ever-increasing market power of global fast-food retailers, such as McDonald's and Kentucky Fried Chicken (KFC), can no longer rely solely on convenience and product consistency as unique selling points (Schröder \& McEachern, 2005). In response, when concerns about fast-food consumption's negative effects bloomed, many fast-food businesses adopted new marketing campaigns (Christian \& Gereffi, 2017). For example, McDonald's began posting energy information on national menus, and Burger King added plant-based foods such as salads and fruit smoothies (Soo et al., 2018). Nutrient profiling is both practical and logical in encouraging public health (Saranya et al., 2016). Although the fast-food industry has begun to do so, ethical problems still exist (Kuan \& Yazdanifard, 2013). There has been evidence the food industry's self-regulation in promoting healthy eating practices has not proved effective in Canada, where children had still been exposed to unhealthy food product marketing (Campbell et al., 2014). This condition leads us to question if we will ever see fast food and beverages consistently offer healthy and ethical choices?

Marketing scientists have defined the marketing mix, which McCarthy (1964) described as the combination of product (goods or services), price (what the consumer pays), promotion (the advertising), and place (where the product is marketed) (4 Ps), as a controllable component that all companies should use to influence consumers' purchasing processes (Sharma et al., 2018). Therefore, the ethical aspects of this marketing mix must be understood, and this study aims to investigate the impact of the perceived ethical aspects of fast-food and beverage companies' 4 Ps strategies on consumers' perceived value and how perceived value positively influences consumers' purchase intentions.

\section{Literature Review and Hypotheses Development}

First, in order to define capitalism, the concept of capital plays a significant role. Based on Karl Marx's view, “capital” is simply "value appropriated without an equivalent" (Marx, 1974a; Marx, 1976). However, Max Weber's definition of capital seems to predominate in contemporary discussions (Smith, 2017). According to Weber, capital is "the money value of the means of profit-making available to the enterprise at the balancing of the books" (Weber, 1978), which helps to build relatively the closest definition of capitalism. Capitalism emerges when we find the property is an object of trade and is utilized by individuals for profit-making 
enterprise in a market economy (Weber, 1976). Therefore, we regard those giant global fastfood and beverage companies as products of institutional transformation which emerges under the circumstances of capitalism in order to deal with real problems in this article.

\subsection{The 4 Ps}

Generally, fast food and carbonated drinks can be defined as products served instantly and ondemand (Xiao et al., 2018) and that has become popular due to their affordable prices and convenience. Many people are now aware that these can harm their health (Kuan \& Yazdanifard, 2013), which has prompted many beverage and fast-food companies to make efforts to promote healthier products.

This present research focuses on ethical issues in the fast-food and beverage industries, and the literature review relates to the perceived ethical aspects of fast-food and beverage companies' products, pricing, placing, and promotion and their impact on perceived value and customer intention.

\subsubsection{Perception of an ethical product}

As consumers demand healthy and safe food has increased in recent years, they have begun to evaluate the nature of the food production process (Schröder, 2005). Some recent food-related studies have found that consumers expect fast-food restaurants not only to ensure their health and safety (Cheng et al., 2018) but also to disclose their ethical practices and procedures transparently.

Fast-food restaurants' corporate social responsibility (CSR) practices, such as promoting healthy eating campaigns and serving more eco-friendly products, can be ways to save resources and protect the environment (Cheng et al., 2018). CSR ensures food safety practices are continuously improved and minimizes the risk of future food safety issues. Following the CSR Practices has led most in the beverage and fast-food industries to enhance their products' quality proactively, avoid using the harmful or dangerous material, and commit to sustaining and protecting environmental resources and their consumers' health.

Fast-food and beverage companies' target audiences are those who not only look for a pleasant fast-food experience but also consider the company's reputation (Weebly, n.d.). Moreover, an increasing eating-out trend has been accompanied by clients considering more than a restaurant's food quality when deciding where to eat. Restaurants are now expected to provide healthy ingredients, such as organic or animal-welfare-friendly produced food, and this boosts the fast-food restaurant's positive reputation (Karki \& Panthi, 2018).

Fast-food and beverage companies use labelling information to inform consumers that their supply reports are legal, credible, and reliable. Specific product sustainability labels and logos are usually displayed on the packaging, and the labelling systems inform individuals of critical nutrients, fats, salt, sugars, and use of red, amber, and green colours (The Coca-Cola Company, 
2018). Previous research has shown that sustainable product packaging positively influences perceived brand ethics and consumers' buying intentions (Magnier et al., 2016).

\subsubsection{Perception of ethical pricing}

Addressing value and affordability has always been part of the fast-food and beverage industries' overall strategies (Xiao et al., 2018). Products and services are difficult to definitively price because the value of the goods or services is related to consumer satisfaction. Therefore, for consumers, the price has become the most influential factor when estimating goods' or services' value (Karki \& Panthi, 2018).

Most fast-food chains and beverage companies see themselves as purveyors of quality food delivered with prompt best-quality service at affordable, transparent prices and offer good value for the money (Begum, 2015). As a result, fast-food industries and beverage companies have a wide client base, many of whom can afford to partake of their products regularly.

Researchers have found it is a myth that customers only care about price. Consumers care more about whether prices are sensible and honest, and products are delivered by ethically accountable businesses (Kim, 2015). In particular, consumers depend on multiple reference sources to compare the cost of products sold, prior prices, and competitors' prices when assessing price fairness and making purchasing decisions (Hanaysha, 2016).

\subsubsection{Perception of ethical placing}

Physical accessibility of products is a critical challenge for both companies and consumers (Sharma et al., 2018). Over the past century, the fast-food restaurant industry has expanded at an accelerated pace, and within the marketing mix elements, the locations where products are provided and where customers can access them (placing) has become important. A perceived high-quality restaurant environment also creates a positive image for a fast-food or beverage brand. Therefore, when consumers consider a restaurant to be of high quality, they tend to be more satisfied with its service, and there is a greater probability the consumer will make a return visit to the restaurant.

Restaurants are the most prominent places to distribute fast-food and beverage products. Therefore, an effective placing strategy of the fast-food and beverage industries is to situate the outlet/distribution centres close to consumers for easy and quick access.

Besides, ethical behaviour is further related to the business's employees' ethical behaviours that eventually promote a long-term connection between staff and consumers based on allegiance and trust, which, in turn, encourages consumers to return to the fast-food or beverage product shop or outlet.

\subsubsection{Perception of ethical promotion}


Promotion is a market activity that connects clients to products by facilitating access to merchandise shops and generates revenue (Sharma et al., 2018). Since the 1990s, several public and private initiatives have endeavoured to communicate sustainability-related information about food to consumers to promote an ethical perception. It is widely thought that responsible food consumption and nutritional decisions can make a significant contribution to meeting present environmental problems and motivate individuals to eat more sustainably (Grunert et al., 2013).

One means of promotion is packaging design, which may influence consumers' perceptions of a brand and its ethics. Many companies in the fast-food and beverage industries have recently undertaken to ensure products' packaging come from renewable, recycled, or certified sources in an attempt to eliminate waste (e.g., soft drinks companies are converting from throwaway to recyclable plastic bottles).

Presently, fast-food and beverage companies seem to be using educative, not manipulative, tactics (e.g., television advertising) to promote their healthy range of product options. Therefore, they hope in that way, and consumers will be more likely to buy these products than traditional unhealthy versions.

\subsection{Hypotheses Development:}

Perceived added value was formerly product-centred, and something organizations could control. Currently, however, customers assume organizations should indulge them by providing desirable experiences. Moreover, several researchers have found that the consumer's perceived value is one main positive factor in a consumer purchasing decision. Consequently, maximizing perceived value for a customer is a company's winning tactic for long-term business success. It has also been assumed that if customers establish reliable interactions with a service provider, this will lead to multiple benefits such as a positive brand image, higher customer loyalty, and increased profit.

The limited amount of research work in this area means there is undoubtedly a need for academic evaluation of all 4 Ps to explain how perceived value leads to consumers' purchase intentions in fast-food restaurants and the beverage industry. The hypotheses developed in this study are, therefore based on how ethical perceptions of all 4 Ps influence perceived value.

\subsubsection{Hypothesis 1 (H1): How perceived ethical products' aspects affect the perceived value}

The perceived quality of food and drinks serves as an essential indicator of fast-food and beverages consumers' satisfaction. The ethical perception of food and drink products focuses on ingredients, range of food products, and drinks offered, among other things (Namin, 2017). The fast-food and beverages industries' notable ethical initiatives are linked to health. For instance, McDonald's is now providing fruits and nutritional advice and encouraging children to participate in physical activities. These perceived ethical actions can have a positive effect on customer satisfaction, which positively influences the perceived value of the products. 
Also, consumers now seek fresh products (Karki \& Panthi, 2018) and put a priority on organic and environmentally friendly foods (Magnier et al., 2016), and when companies provide these, that may improve their perceived value (Lu \& Gursoy, 2017).

Lastly, each restaurant's success relies on the ethical aspects related to the products it sells, its performance, and its clients' perspectives. Namin (2017) found that the relationship between the perceived value of the product and product quality in fast-food restaurants has a direct and significant positive effect on consumer satisfaction from food quality. These findings lead to proposing hypothesis H1: Perceived ethical aspects of products in fast-food restaurants and beverage industries significantly influence customer satisfaction and perceived value of the company.

\subsubsection{Hypothesis $2(\mathrm{H} 2)$ : How perceived ethical pricing aspects affect the perceived value}

Food pricing shapes individual decisions because most consumers tend to focus on the product price when buying a meal. Studies have empirically demonstrated that price data and expectations of quality affect value decisions and have emphasized the importance of price perception among consumers (Hanaysha, 2016).

Perceived price fairness can be described as the consumer's estimate whether the distinction or absence of difference between the seller's price and a competitor's price in a transaction is fair, sensible, and justifiable (Rothenberger, 2015). Consumers often use price as a cue when appraising products, and they form their attitudes towards fast-food and beverage companies based on price. So, if a business can offer higher price transparency, consumers view the price as fairer.

Research has also shown that consumers consider a product's price and then compare it with a product's perceived benefits. In particular, some research shows that perception of price can influence perceived value because perceived value represents the combination of perceived benefits and perceived sacrifices related to a product (Namin, 2017). These findings lead to proposing hypothesis $\mathrm{H} 2$ : Perceived ethical aspects of the price will trigger a positive influence on the perceived value of fast-foods and beverage products.

\subsubsection{Hypothesis $3(\mathrm{H} 3)$ : How perceived ethical placing affects perceived value}

Empirical evidence has verified that consumer food purchases are considerably affected by the convenience of the restaurant (Sharma et al., 2018). In 2017, McDonald's Corporation (2017) added a delivery option to 7,000 of its restaurants in 21 different countries, and now, the restaurant delivers meals from over 10,000 restaurants. Consequently, they added a convenience factor to their service, which may have affected perceived value.

In addition, fast-food and beverage companies, such as McDonald's, are committed to creating an environment that values and respects its employees, recognizes and rewards their performance, and provides them meaningful growth opportunities. As in McDonald's case, its owners/operators and suppliers work together to create exceptional experiences in the 
restaurant, strengthen relationships within the communities, and enhance the social relationship between customers and employees (McDonald's Corporation, 2000). These initiatives can be expressed in hypothesis H3: Perceived ethical placing is expected to trigger a positive influence on the perceived value of fast-foods and beverage products.

\subsubsection{Hypothesis 4 (H4): How perceived ethical promotion affects perceived value}

Ethical promotion includes restaurants' strict adherence to accountable food and beverage marketing methods that comply with recommended nutrient goals to support useful dietary guidelines (Kraak et al., 2017). Therefore, some ethical promotional measures restaurants use involve restaurant managers providing information, such as menu labelling, and motivational messages and/or contextual data to assist consumers in selecting high-quality products at the preferred choice and purchase points.

Big fast-food brands, like McDonald's and Subway, have introduced sustainability programs that have been conveyed through publishing their sustainability records, promoting their corporate images through news reports or releases (Kim \& Ramos, 2018), and launching corporate websites focused on corporate social responsibility, which previous research has shown plays a role in the food industry companies' perceived value.

Restaurants have uniformly embraced the ethical menu by using menu design elements (i.e., visuals and positioning) in their marketing to emphasize new, regional, and unprocessed foods and beverage goods to consumers, and they have implemented policies to restrict the promotion of higher fat, sugary, and tangy food and beverage products to young people (Kraak et al., 2017). These initiatives can be expressed in hypothesis H4, ethical promotional measures positively affect the perceived value of a product.

\subsubsection{How perceived value affects consumers' purchase intentions}

Perceived value connected to a product or service is one of the standard criteria of selection among consumers (Konuk, 2019). Perceived value can lead to consumer satisfaction and also purchasing intentions (Konuk, 2019). Therefore, analyzing the perceived value's influence on consumer purchase intention is crucial.

Consumer satisfaction is usually defined as how consumers evaluate performance after using a product or how they assess production services by comparing them with products from other businesses in the same sector. Further, in exploring a consumer's evaluation of products and services, purchase intention is accountable for determining whether a product met the expectations and needs of the consumer. Hence, purchase intention can be the key to promoting a long-term business's success and to accumulating consumers' lifetime loyalty.

Purchase intention is considered an essential factor because it helps to understand consumer behaviour, and it functions as a predictor of purchasing behaviour (Xiao et al., 2018). Therefore, knowing how perceived value influences purchase intention toward fast-food restaurants can inform promotion strategies. The relationship between perceived value and purchase intention 
can be conveyed through hypothesis H5: Perceived value can positively influence intention to consume unhealthy foods.

\section{Research Method}

\subsection{Participants and Procedures}

This study used a convenience non-probability sampling technique to approach the respondents in different countries using Amazon's Mechanical Turk (MTurk) platform, which, in many recent studies, has been considered a reliable and valid psychological data source (Buhrmester et al., 2011; Hasan et al., 2018; Paolacci et al., 2010). Even though convenience sampling is not a consistently generalizable method, it seemed the most practical approach and has been frequently used by scholars (Churchill \& Iacobucci, 2010).

MTurk also allowed us to collect a wide variety of demographic and geographic data (Berinsky et al., 2012; Buhrmester et al., 2011), such as from the United States, United Kingdom, India, Canada, Germany, Italy, Mexico, Cuba, Turkey, etc. The MTurk respondents received, on average \$0.5 USD per survey. Descriptive statistics of the respondents are presented in Table 1.

<Insert Table 1 about here>

Initially, we received 1,275 responses; however, we deleted 17 incomplete responses and 13 responses that failed the attention-check question. Therefore, the final sample size was 1,245 responses. In line with Hair et al.'s (2010) recommendation that the sample size should preferably include over 100 participants to use structural equation modelling appropriately, this study's sample size greatly exceeded this recommended level.

The respondents first answered a screening question that revealed how they had heard about food brands, such as A (A famous fast-food company) and B (A famous Beverage Company). We will be using the name $\mathrm{A}$ and $\mathrm{B}$ throughout this paper to protect the privacy of these companies. In the first section of the survey, we collected demographic information of the respondents. In the next section, we asked questions related to intention, perceived ethical placing, perceived ethical pricing, perceived ethical product, perceived ethical promotion, and perceived value. The survey lasted approximately 16 to 20 minutes.

\subsection{Measures}

We used a seven-point Likert scale for the majority of the scales because it captures more significant variation than the five-point Likert scale (Finstad, 2010). Most of this study's items were adapted from well-established sources. Items of Intention contract were adapted from Davis et al. (1989), Schierz et al., (2010), Venkatesh and Davis (2000), and Venkatesh et al. (2003); Items of Perceived Value were adapted from Sirdeshmukh et al. (2002). However, Perceived Ethical Placing, Perceived Ethical Pricing, Perceived Ethical Product, and Perceived Ethical Promotion constructs were not found in the literature, although they resemble existing constructs. Therefore, instead of creating new measures, the literature yielded constructs with 
accompanying measures that overlapped in definition, and the measures were adapted from Yoo et al. (2000).

Next, we refined the measures using scale development procedures based on Cao et al. (2005), Hsu et al. (2004), Moore and Benbasat (1991), So et al. (2005), Tsang and Tse (2005), and Wee and Quazi (2005). This procedure consisted of (a) assessing the content validity of constructs through expert evaluation, (b) pre-testing and pilot testing, (c) testing internal consistency, and (d) testing construct validity through tests of convergent and discriminant validity. The modification of any items was based on an extensive literature review (e.g., Gaski, 1999) and inter-rater agreement based on ambiguity, similarity, and relevance (Francis et al., 2004). Table 2 displays the constructs and items for measurement.

<Insert Table 2 about here>

\subsection{Statistical Analysis}

We used Partial Least Squares-based (PLS-based) Structural Equation Modelling (SEM) to analyze the measurement model and the structural model. PLS-SEM was appropriate for this study because it is suitable to test the phenomenon in early stages of development (Fornell \& Bookstein, 1982). Also, PLS-SEM does not require a multivariate-normal distribution (Albert \& Merunka, 2013).

\section{Results}

\subsection{Measurement Model}

We tested the reliability and validity of each construct using Smart PLS 3.0 and ran a bootstrapping sample of 5,000 to test this study's measurement model. To do so, we assessed the convergent validity, reliability, and discriminant validity of all constructs. To assess convergent validity, we conducted a confirmatory factor analysis (CFA) to ensure the measurement model's reliability and validity. Table 3 gives confidence that all items appropriately loaded within their theoretical constructs. Next, Cronbach's alpha and the composite reliability of each construct were assessed using PLS-SEM (Lowry \& Gaskin, 2014). Each construct represents a greater degree of reliability than the recommended threshold of 0.70 , as it is listed in Table 3 (Chin, 1998). Furthermore, discriminant validity of the measurement model was assessed and is presented in Table 4 in which diagonal numbers present the square roots of average variance extracted (AVE), and the interconstruct correlations are presented by off-diagonal numbers. Table 4 provides evidence of appropriate discriminant validity as the square roots of AVE are more significant than the interconstruct correlations (Lowry \& Gaskin, 2014).

<Insert Table 3 about here> 
<Insert Table 4 about here>

\subsection{Structural Model and Analysis}

The results of the structural model test are presented in Figure 1, where path coefficients present the strength of relationship between dependent and independent constructs, and R-squared values present the variance that is explained by independent constructs.

$<$ Insert Figure 1 about here>

From Figure 1, it appears that perceived ethical product has a significant positive influence on the perceived value of unhealthy victuals $(\beta=0.185, \mathrm{p}<0.05)$, and it supports hypothesis $\mathrm{H} 1$. The influence of perceived ethical product was found to be controlled by gender in such a way that the influence is greater for male consumers $(B=-0.075, \mathrm{p}<0.05)$. Perceived ethical pricing was found to have a significant positive influence on the perceived value of unhealthy victuals $(\beta=0.384, p<0.05)$, and it supports hypothesis $H 2$. The influence of perceived ethical placing has a significant positive influence on the perceived value of unhealthy victuals $(\beta=0.098, \mathrm{p}<$ $0.05)$, and it supports hypothesis H3. The influence of perceived ethical placing was found to be controlled by gender in such a way that the influence is greater for female consumers $(\beta=$ $0.092, \mathrm{p}<0.05)$. In addition, perceived ethical promotion was found to have significant positive influence on perceived value of unhealthy victuals $(B=0.210, p<0.05)$, and it supports hypothesis H4. Perceived value was found to have significant positive influence on intention to consume unhealthy victuals $(\beta=0.582, \mathrm{p}<0.05)$, and it supports hypothesis H5.

The influence of perceived value was found to be controlled by age in such a way that the influence is greater for older consumers $(\beta=0.031, p<0.05)$. The influence of perceived value was found to be controlled by the ability to identify unhealthy victuals in such a way that the influence is greater for consumers who do not recognize fast foods and carbonated drinks as unhealthy victuals $(\beta=-0.075, \mathrm{p}<0.05)$.

It appears that perceived ethical pricing has a stronger influence on perceived value compared to the perceived ethical product, perceived ethical placing, and perceived ethical promotion. The R-square value of the perceived value of unhealthy victuals is 64.40 percent; therefore, a 64.40 percent variance of perceived value is explained by perceived ethical product, perceived ethical pricing, perceived ethical placing, and perceived ethical promotion.

The R-square value of intention to consume unhealthy victuals is 65.40 percent, which indicates the perceived value of unhealthy victuals explains a 65.40 percent variance of intention to consume unhealthy victuals.

\subsection{Multigroup Analysis}


In this study, the multi-group analysis was conducted to investigate whether the path coefficient of the proposed theoretical model would significantly differ between A (A popular fast-food company) and B (A popular Beverage Company). Initially, the total sample was divided into two subsamples (i.e., A and B). Next, the path model of each subsample was estimated, and these results are presented in Table 5. We followed the multi-group analysis procedure suggested by Henseler (2007) and used the bootstrapping results of each subsample to investigate any significant differences between the two subsamples.

From the last column of Table 5 (MGA [ $\beta \mathrm{A}-\beta \mathrm{B}]$ ), significant differences appeared: perceived ethical pricing $\rightarrow$ perceived value path coefficient was higher for the A subsample ( $\beta=0.493$, $\mathrm{p}<0.05)$ than for the $B$ subsample $(\beta=0.275, \mathrm{p}<0.05)$. Furthermore, the influence of perceived value on intention was higher in the A subsample $(\beta=0.634, \mathrm{p}<0.05)$ than the $\mathrm{B}$ subsample $(\beta=0.537, \mathrm{p}<0.05)$

\section{<Insert Table 5 about here>}

\section{Discussion}

The present research revealed that the ethical aspects of a marketing mix could consist of four components (product, price, promotion, and placing strategies) in the context of fast-food restaurants and the beverage industry. These results are based on testing the hypotheses to analyze how ethical perception of the four marketing mix components can influence perceived value, which, in turn, leads to consumers' purchase intention (an important aspect to evolving restaurants' success) in the context of fast-food restaurants.

Previous research by Kraak et al. (2017) suggested that restaurant business models promote consumers choosing and eating healthy foods and beverages to support healthy food environments and avoid obesity. Kim \& Ramos (2018) concluded that the fast-food industry's notable ethical initiatives are always linked to health. For example, some fast-food chains have launched health-related initiatives aimed at minimizing the damage fast-food can inflict on public health, and sustainability programs focused on a broad spectrum of fields, including nutrition, overall well-being, children's fitness, environmental problems, and engagement with local communities. This finding also proves ethical actions taken by the fast-food and beverage industries lead to the perceived value of products. This result supports the relationship between the perceived ethical product and the perceived value of the company with a coefficient of 0.185 .

Jang's (2015) empirical research findings revealed that regarding price, McDonald's has a comparatively greater perceived value. In line with prior research (Konuk, 2019), the beneficial role of price fairness on perceived value has also been endorsed in this research. The results of this study show that among the four marketing mix components, the pricing factor mainly influences perceived value. This finding shows consumers are willing to pay a higher price for product safety. The results of the testing of hypothesis $\mathrm{H} 2$ are supported, and the relationship between perceived ethical pricing and perceived value is at a significant level (0.384). This 
value is at the highest level when compared to other marketing mixes considered in this research work.

Sharma et al. (2018) confirmed that the placement element is an important factor that leads to the perceived value of food products. Similarly, the current research supports hypothesis H3, and the relationship between perceived ethical placing and perceived value is relatively at the lowest level, with a coefficient of 0.098, among the other marketing mix components considered for this research. Ethical placing strategy for food products was redefined to include: restaurant closeness/less travel, facility of credit, respectful treatment, regular cost and high quality of the product, shopkeeper's product expertise, and familiar/trust with a local shopkeeper, which reflects the positive image of the restaurant (Sharma et al., 2018).

Wongprawmas and Canavari's (2017) study results revealed consumers are willing to pay more for anything they perceive to guarantee the product safety, and promotion plays an important role in convincing consumers of a product's quality and safety. Kraak et al. (2017) suggested responsible food and beverage promotion practices, such as labelling products, introducing enhanced food safety standards, and meeting recommended nutrition targets to support healthy dietary guidelines, are worthwhile. Besides, they concluded restaurants that have developed and enforced a policy to limit the promotion of high fat, high sugar, and salty foods and drink products for young people through celebrity endorsement, digital marketing, and other promotion mediums are perceived as offering value. Sharma et al. (2018) also suggested that the promotion factor has a positive impact on consumers' perceived value and purchase intentions.

The present study supports these authors' conclusions, and hypothesis H4 was positively supported: the relationship between perceived value and perceived ethical promotion had a coefficient of 0.210. Ethical promotion involves restaurants' rigorous commitment to responsible food and beverage marketing techniques that promote products that meet suggested dietary objectives to promote healthy nutritional guidelines. Perceived value is one important factor that highly influences consumers' purchase intentions and satisfaction.

\section{Conclusion}

The results show how the perceived ethical aspects of products involving price, promotion, and placing strategies of fast-food and beverage industries influence perceived value by consumers. This study further proves that perceived value positively influences consumers' purchase intentions; therefore, to measure any company's success, purchasing intention in the market is an essential consideration. In conclusion, perceived ethical aspects of products for fast-food restaurants and beverages are beneficial for consumers. Consequently, the policy of ethics in all the considered marketing mix deserves support in the restaurant and beverage industries.

\section{References}

Albert, N. and Merunka, D. (2013). The role of brand love in consumer-brand relationships, Journal of Consumer Marketing, 30(3), pp. 258-266. 
Begum, V. (2015). UAE consumer rejoinder towards McDonald's sales promotion strategy in Dubai. 2nd Global Conference on Business and Social Science-2015, Bali, Indonesia. Procedia-Social and Behavioral Sciences, 211(2015), 61-68. Retrievable at https://www.sciencedirect.com/science/article/pii/S1877042815053501

Berinsky, A., Huber, G., \& Lenz, G. (2012). Evaluating online labor markets for experimental research: Amazon.com's Mechanical Turk. Political Analysis, 20(3), 351-368.

Buhrmester, M. D., Kwang, T., \& Gosling, S. D. (2011). Amazon's Mechanical Turk: A new source of inexpensive, yet high-quality data? Perspectives on Psychological Science, 6(1), $3-5$.

Campbell, N., Pipe, A., \& Duhaney, T. (2014). Calls for restricting the marketing of unhealthy food to children: Canadian cardiovascular health care and scientific community get ignored by policy makers. What can they do? Canadian Journal of Cardiology, 30(5), 479-481.

Cao, M., Zhang, Q., \& Seydel, J. (2005). B2C e-commerce web site quality: an empirical examination. Industrial Management \& Data Systems, 105(5), 645-661.

Churchill, G. A., \& Iacobucci, D. (2010). Marketing research: Methodological foundations. Mason: South-Western Cengage Learning.

Cheng, T., Tong, C., \& Wong, A. T.-T. (2018). The impact of corporate social responsibility and food health and safety, on the corporate image of Hong Kong's fast-food restaurants. Asian Research Journal of Arts \& Social Sciences, 7(2), 1-18.

Chin, W. W. (1998). The partial least squares approach to structural equation modeling. Modern Methods for Business Research, 295(2), 295-336.

Christian, M., \& Gereffi, G. (2018). Fast-food value chains and childhood obesity: A global perspective. In M. Freemark (Ed.), Pediatric obesity (Contemporary Endocrinology Series, pp. 717-730). Cham, Switzerland: Humana Press.

Cunningham, A. (2003). Autonomous consumption: Buying into the ideology of capitalism. Journal of Business Ethics, 48(3), 229-236.

Davis, F. D., Bagozzi, R. P., \& Warshaw, P. R. (1989). User acceptance of computer technology: A comparison of two theoretical models. Management Science, 35(8), 9821003.

Karki, D., \& Panthi, A. (2018). How food quality, price, ambiance and service quality effects customer satisfaction: A study on Nepalese restaurants in Finland. (Bachelor's thesis). Haaga Helia University of Applied Sciences, Finland. Retrievable at https://www.theseus.fi/bitstream/handle/10024/150964/Dipesh\%20and\%20Apil\%20Custo mer\%20Satisfaction $\% 20 \mathrm{in} \% 20$ Nepalese $\% 20$ Restaurantsin $\% 20$ Finland.pdf?sequence $=1 \& \mathrm{i}$ sAllowed=y

Finstad, K. (2010). Response interpolation and scale sensitivity: Evidence against 5-point scales. Journal of Usability Studies, 5(3), 104-110.

Fornell, C., \& Bookstein, F. L. (1982). Two structural equation models: LISREL and PLS applied to consumer exit-voice theory. Journal of Marketing Research, 19(4), 440-452. 
Francis, J. J., Eccles, M. P., Johnston, M., Walker, A., Grimshaw, J., Foy, R., ... and Bonetti, D. (2004). Constructing questionnaires based on the theory of planned behavior: A manual for health services researchers. Newcastle upon Tyne, UK: Centre for Health Services Research, University of Newcastle upon Tyne. Retrievable at https://openaccess.city.ac.uk/id/eprint/1735/1/TPB\%20Manual\%20FINAL\%20May2004. pdf

Gaski, J. F. (1999). Does marketing ethics really have anything to say?-A critical inventory of the literature. Journal of Business Ethics, 18(3), 315-334.

Hair, J. F., Jr., Black, W. C., Babin, B. J., \& Anderson, R. E. (2010). Multivariate data analysis. A global perspective. Upper Saddle River, NJ: Pearson.

Hanaysha, J. (2016). Testing the effects of food quality, price fairness, and physical environment on customer satisfaction in fast food restaurant industry. Journal of Asian Business Strategy, 6(2), 31-40.

Hasan, M. R., Jha, A. K., \& Liu, Y. (2018). Excessive use of online video streaming services: Impact of recommender system use, psychological factors, and motives. Computers in Human Behavior, 80(March), 220-228.

Henseler, J. (2007). A new and simple approach to multi-group analysis in partial least squares path modeling. Paper presented at the 5th International Symposium on PLS and Related Methods (PLS’ 07) (Oslo, Norway).

Hsu, M. H., Chiu, C. M., \& Ju, T. L. (2004). Determinants of continued use of the WWW: An integration of two theoretical models. Industrial Management \& Data Systems, 104(9), 766-775.

Izquierdo-Yusta, A., Gómez-Cantó, C. M., Pelegrin-Borondo, J., \& Martínez-Ruiz, M. P. (2018). Consumers' behaviour in fast-food restaurants: A food value perspective from Spain. British Food Journal, 121(2),386-399.

Jang, Y. (2015). Perceived value of fast-food restaurants Franchises in the USA (Electronic theses and dissertations) Florida International University Miami, Florida. doi: http://dx.doi.org/10.25148/etd.FI15032187

Kim, Y. (2015). Consumer responses to the food industry's proactive and passive environmental CSR, factoring in price as CSR tradeoff. Journal of Business Ethics, 140(2), 307-321.

Kim, Y., \& Ramos, M. L. Z. (2018). Stakeholder responses toward fast food chains' CSR. Corporate Communications: An International Journal, 23(1), 117-138.

Grunert, K. G., Hieke, S., \& Willis, J. (2013). Sustainability labels on food products: Consumer motivation, understanding and use. Food Policy, 44(February), 177-189.

Konuk, F. A. (2019). The influence of perceived food quality, price fairness, perceived value and satisfaction on customers' revisit and word-of-mouth intentions towards organic food restaurants. Journal of Retailing and Consumer Services, 50(C), 103-110. 
Kraak, V. I., Englund, T., Misyak, S., \& Serrano, E. L. (2017). A novel marketing mix and choice architecture framework to nudge restaurant customers toward healthy food environments to reduce obesity in the United States. Obesity Reviews: An Official Journal of the International Association for the Study of Obesity, 18(8), 852-868. doi: 10.1111/obr.12553

Kuan, T. L., \& Yazdanifard, R. (2013). The review of ethical issues that companies faces during fast food marketing and advertising campaign. Retrievable at https://www.researchgate.net/publication/253503997_The_Review_Of_Ethical_Issues_Th at_Companies_Faces_During_Fast_Food_Marketing_And_Advertising_Campaign

Magnier, L., Schoormans, J., \& Mugge, R. (2016). Judging a product by its cover: Packaging sustainability and perceptions of quality in food products. Food Quality and Preference, 53(October), 132-142.

Lowry, P. B., \& Gaskin, J. (2014). Partial Least Squares (PLS) Structural Equation Modeling (SEM) for building and testing behavioral causal theory: When to choose it and how to use it. IEEE Transactions on Professional Communication, 57(2), 123-146.

Lu, L., \& Gursoy, D. (2017). Does offering an organic food menu help restaurants excel in competition? An examination of diners' decision-making. International Journal of Hospitality Management, 63(May), 72-81.

Marx, K. (1974a). Capital, vol. I. London: Lawrence \& Wishart.

Marx, K. (1976). Capital, vol. I. London: Penguin Books.

McCarthy, E. J. (1964). Basic marketing. Homewood, IL: Richard D. Irwin.

McDonald's Corporation. (2017). United States Securities and Exchange Commission Form 10-K: Annual report pursuant to section 13 or 15(d) of the Securities Exchange Act of 1934 for the fiscal year ended December 31, 2017: McDonald's Corporation. Retrievable at https://corporate.mcdonalds.com/content/dam/gwscorp/nfl/investor-relationscontent/annual-reports/McDonald\%27s\%202017\%20Annual\%20Report.pdf

McDonald's Corporation. (2000). McDonald's Corporation annual report. Oakbrook, IL: McDonald's Corporation. Retrievable at https://www.zonebourse.com/MCDONALDS-CORPORATION4833/pdf/71649/McDonald's\%20Corporation_Rapport-annuel.pdf

Moore, G. C., \& Benbasat, I. (1991). Development of an instrument to measure the perceptions of adopting an information technology innovation. Information Systems Research, 2(3), 192-222.

Namin, A. (2017). Revisiting customers' perception of service quality in fast food restaurants. Journal of Retailing and Consumer Services, 34(C), 70-81.

Paolacci, G., Chandler, J., \& Ipeirotis, P. G. (2010). Running experiments on Amazon Mechanical Turk. Judgment and Decision Making, 5(5), 411-419.

Rothenberger, S. (2015 March). Fairness through transparency: The influence of price transparency on consumer perceptions of price fairness. Université Libre de BruxellesSolvay Brussels School of Economics and Management Centre Emile Bernheim Working 
Papers CEB 15-008, ULB, Brussels, Belgium. Retrievable at https://pdfs.semanticscholar.org/ff97/cf4edc4cb5b6bafa48228af96e4634dee96c.pdf?_ga= 2.141026162.1380549043.1580228193-600770183.1569616347

Saranya, P. V., Shanifa, N., Shilpa, S., Simy. T., Umarani, J., \& Shetty, A. P. (2016). Adolescents' knowledge regarding the effects of fast food on health. International Journal of Current Medical Research, 5(3), 406-409.Retrievable at https://www.researchgate.net/publication/308154628_Adolescents'_Knowledge_Regardin g_the_Effects_of_fast_food_on_Health

Schierz, P. G., Schilke, O., \& Wirtz, B. W. (2010). Understanding consumer acceptance of mobile payment services: An empirical analysis. Electronic Commerce Research and Applications, 9(3), 209-216.

Schröder, M. J. A., \& McEachern, M. G. (2005). Fast foods and ethical consumer value: a focus on McDonald's and KFC. British Food Journal, 107(4), 212-224.

Sharma, Y., Nasreen, R., \& Kumar, A. (2018). Impact of marketing-mix for core-food items on purchase behavior at subsistence marketplace-An empirical study of urban subsistence market of Delhi. Global Journal of Management and Business Research: E Marketing, 18(3-E), 4-19. Retrievable at https://journalofbusiness.org/index.php/GJMBR/article/view/2469

Sirdeshmukh, D., Singh, J., \& Sabol, B. (2002). Consumer trust, value, and loyalty in relational exchanges. Journal of Marketing, 66(1), 15-37.

Smith, K. (2017). Capitalism. The Wiley - Blackwell Encyclopedia of Social Theory, 1-8.

So, W. M., Wong, T. D., \& Sculli, D. (2005). Factors affecting intentions to purchase via the internet. Industrial Management \& Data Systems, 105(9), 1225-1244.

Soo, J., Harris, J. L., Davison, K. K., Williams, D. R., \& Roberto, C. A. (2018). 20). Changes in the nutritional quality of fast-food items marketed at restaurants, 2010 v. 2013. Public Health Nutrition, 21(11), 2117-2127.

Sprott, D. E. (2008). The policy, consumer, and ethical dimensions of covert marketing: An introduction to the special section. Journal of Public Policy \& Marketing, 27(1), 4-6.

Tepper, J. (2018). The myth of capitalism: monopolies and the death of competition. John Wiley $\&$ Sons.

The Coca-Cola Company. (2018). Business and sustainability report. Retrievable at https://www.coca-colacompany.com/content/dam/journey/us/en/policies/pdf/safetyhealth/coca-cola-business-and-sustainability-report-2018.pdf

Tsang, P. M., \& Tse, S. (2005). A hedonic model for effective web marketing: An empirical examination. Industrial Management \& Data Systems, 105(8), 1039-1052.

Venkatesh, V., \& Davis, F. D. (2000). A theoretical extension of the technology acceptance model: Four longitudinal field studies. Management Science, 45(2), 186-204.

Venkatesh, V., Morris, M. G., Davis, G. B., \& Davis, F. D. (2003). User acceptance of information technology: Toward a unified view. MIS Quarterly, 27(3), 425-478. 
Weber, M. (1978). Economy and society: An outline of interpretive sociology (Vol. 1). Univ of California Press.

Weber, M. (1976). The agrarian sociology of ancient civilizations, trans. RT Frank. London: NLB.

Wee, Y. S., \& Quazi, H. A. (2005). Development and validation of critical factors of environmental management. Industrial Management \& Data Systems, 105(1), 96-114.

Weebly. (n.d.). Ethics of McDonalds. Retrievable at https://mcdonaldsethics.weebly.com/

Wongprawmas, R., \& Canavari, M. (2017). Consumers' willingness-to-pay for food safety labels in an emerging market: The case of fresh produce in Thailand. Food Policy, 69(C), 25-34. https://doi.org/10.1016/j.foodpol.2017.03.004

Xiao, A., Yang, S., \& Iqbal, Q. (2018). Factors affecting purchase intentions in Generation Y: An empirical evidence from fast food industry in Malaysia. Administrative Sciences, 9(1), $1-16$.

Yoo, B., Donthu, N., \& Lee, S. (2000). An examination of selected marketing mix elements and brand equity. Journal of the Academy of Marketing Science, 28(2), 195-211.

\section{Authors' biographies}

Rajibul Hasan is an Assistant Professor of Marketing at Maynooth University, Ireland. Previously, he worked as an Assistant Professor at Rennes School of Business and he worked as a principal investigator in the Artificial Intelligence (AI) \& consumer behaviour research area of excellence. He specializes in understanding consumer behaviour and innovation adoption. He has published in academic journals.

Zhirun YU is a Postgraduate of MSC, majoring in Master of Arts in International Business at Rennes School of Business, Rennes, France. She is interested in international marketing, consumer behavior, innovation adoption, emerging market, poverty alleviation and technology management. 
Table 1 Descriptive Statistics

\begin{tabular}{l|r|r}
\hline \multicolumn{1}{c}{ Variable Definition } & & Percent \\
\hline Gender & 799 & $64.20 \%$ \\
\hline Male & 446 & $35.80 \%$ \\
\hline Female & & \\
\hline $18-25$ & 248 & $19.92 \%$ \\
\hline $26-40$ & 790 & $63.45 \%$ \\
\hline $41-55$ & 124 & $9.96 \%$ \\
\hline $55-68$ & 72 & $5.78 \%$ \\
\hline $69+$ & 11 & $0.89 \%$ \\
\hline Education Level & & \\
\hline High school and below & 165 & $13.25 \%$ \\
\hline Bachelor's degree & 746 & $59.92 \%$ \\
\hline Master's degree & 303 & $24.34 \%$ \\
\hline Above Master's degree & 31 & $2.49 \%$ \\
\hline Employment Status & & \\
\hline Working full-time & 1,001 & $80.40 \%$ \\
\hline Working part-time & 152 & $12.21 \%$ \\
\hline Retired & 25 & $2.01 \%$ \\
\hline Homemaker & 26 & $2.09 \%$ \\
\hline Unemployed & 41 & $3.29 \%$ \\
\hline
\end{tabular}


Table 2 Constructs and Items

\section{Intention}

1. Given the opportunity, I will buy

2. I am likely to buy ___ in the near future.

3. I am willing to buy __ in the near future.

4. I intend to buy ___ when the opportunity arises.

\section{Perceived Value}

1. Compared to the price I need to pay, the ___ offers value for money.

2. Compared to the effort I need to put in eating the foods or drinking, eating or drinking is beneficial to me.

3. Overall, the ___ delivers me good value.

\section{Perceived Ethical Product}

1. I consider ___ is a good quality product, and it represents an ethical product.

2. In my opinion ___ is ethical as it is not harmful or dangerous to its customers.

3. is ethical as the reputation of A's is positive.

4. __ is considered as ethical because this company manufactures the product that does not deceive its customers.

5. __ is ethical as the company does not damage the natural environment, resources, and health of customers.

6. is ethical as the product fulfils its purpose of what consumers might expect from fast foods.

\section{Perceived Ethical Placing}

1. is a more ethical brand as its foods are available in many places close to me.

2. Ethical aspects of is related to the positive image of the restaurants in which it is sold.

3. is more ethical as selling its foods enhances social relationships among employees, consumers, and 's within a society.

\section{Perceived Ethical promotions}

1. Ethical aspects of ___ 's seems good as the advertisements of A's are not manipulative.

2. Beautiful packaging of ___s convinces that___ 's is an ethical product.

3. __ 's is ethical as the promotional tools are used to inform customers. (e.g., information about sugar)

4. __ 's is ethical as the company does not use aggressive or forceful promotional tools to sell its foods. 
1.___ 's brand is ethical as the price of ___ 's is perceived as fair value for money.

2. The price of ___ 's is fair as there are no hidden charges.

3. A fair price of ___ 's is a sign of ethical product. 
Table 3 Results of the Measurement Model

\begin{tabular}{|c|c|c|c|c|c|c|c|}
\hline $\begin{array}{c}\text { Construct } \\
\mathrm{s}\end{array}$ & Items & $\begin{array}{c}\text { Factor } \\
\text { Loadin } \\
\mathrm{g}(> \\
0.7) \\
\end{array}$ & $\begin{array}{c}\text { Mea } \\
\mathrm{n}\end{array}$ & $\begin{array}{c}\text { Standard } \\
\text { Deviatio } \\
n \\
\end{array}$ & $\begin{array}{c}\text { Cronbach' } \\
\text { s alpha }\end{array}$ & $\begin{array}{c}\text { Composit } \\
\mathrm{e} \\
\text { Reliabilit } \\
\mathrm{y} \\
\end{array}$ & AVE \\
\hline \multirow{3}{*}{$\begin{array}{l}\text { Perceived } \\
\text { Ethical } \\
\text { Placing }\end{array}$} & PE_placing_1 & 0.891 & $\begin{array}{r}4.72 \\
6 \\
\end{array}$ & 1.450 & 0.870 & 0.920 & $\begin{array}{r}0.79 \\
3 \\
\end{array}$ \\
\hline & PE_placing_2 & 0.891 & & & & & \\
\hline & PE_placing_3 & 0.890 & & & & & \\
\hline \multirow{3}{*}{$\begin{array}{l}\text { Perceived } \\
\text { Ethical } \\
\text { Pricing }\end{array}$} & PE_pricing_1 & 0.885 & $\begin{array}{r}5.09 \\
3\end{array}$ & 1.210 & 0.793 & 0.879 & $\begin{array}{r}0.70 \\
8\end{array}$ \\
\hline & PE_pricing_2 & 0.770 & & & & & \\
\hline & PE_Pricing_3 & 0.864 & & & & & \\
\hline \multirow{6}{*}{$\begin{array}{l}\text { Perceived } \\
\text { Ethical } \\
\text { Product }\end{array}$} & PE_product_1 & 0.893 & $\begin{array}{r}4.74 \\
4 \\
\end{array}$ & 1.332 & 0.914 & 0.933 & $\begin{array}{r}0.70 \\
1 \\
\end{array}$ \\
\hline & PE_product_2 & 0.844 & & & & & \\
\hline & PE_product_3 & 0.868 & & & & & \\
\hline & PE_product_4 & 0.853 & & & & & \\
\hline & PE_product_5 & 0.848 & & & & & \\
\hline & PE_product_6 & 0.707 & & & & & \\
\hline \multirow{4}{*}{$\begin{array}{l}\text { Perceived } \\
\text { Ethical } \\
\text { Promotio } \\
n\end{array}$} & PE_promotion_1 & 0.864 & $\begin{array}{r}4.69 \\
2 \\
\end{array}$ & 1.383 & 0.862 & 0.906 & $\begin{array}{r}0.70 \\
7 \\
\end{array}$ \\
\hline & PE_promotion_2 & 0.817 & & & & & \\
\hline & PE_promotion_3 & 0.848 & & & & & \\
\hline & PE_promotion_4 & 0.834 & & & & & \\
\hline \multirow{5}{*}{ Intention } & Intention_1 & 0.921 & $\begin{array}{r}5.14 \\
8 \\
\end{array}$ & 1.466 & 0.94 & 0.957 & $\begin{array}{r}0.84 \\
8 \\
\end{array}$ \\
\hline & Intention_2 & 0.929 & & & & & \\
\hline & Intention_3 & 0.915 & & & & & \\
\hline & Intention_4 & 0.918 & & & & & \\
\hline & $\begin{array}{l}\text { Perceived_value_ } \\
1\end{array}$ & 0.867 & $\begin{array}{r}5.08 \\
1 \\
\end{array}$ & 1.283 & 0.853 & 0.911 & $\begin{array}{r}0.77 \\
3 \\
\end{array}$ \\
\hline
\end{tabular}

Perceived Perceived_value_ 0.858

Value $\quad 2$

Perceived_value_ 0.913 
Table 4 Discriminant Validity of the Measurement Model

\begin{tabular}{|c|c|c|c|c|c|c|}
\hline & Intention & $\begin{array}{c}\text { Perceived } \\
\text { Ethical } \\
\text { Placing } \\
\end{array}$ & $\begin{array}{c}\text { Perceived } \\
\text { Ethical } \\
\text { Pricing } \\
\end{array}$ & $\begin{array}{c}\text { Perceived } \\
\text { Ethical } \\
\text { Product }\end{array}$ & $\begin{array}{l}\text { Perceived } \\
\text { Ethical } \\
\text { Promotion }\end{array}$ & $\begin{array}{c}\text { Perceived } \\
\text { Value }\end{array}$ \\
\hline Intention & 0.921 & & & & & \\
\hline $\begin{array}{l}\text { Perceived Ethical } \\
\text { Placing }\end{array}$ & 0.637 & 0.891 & & & & \\
\hline $\begin{array}{l}\text { Perceived Ethical } \\
\text { Pricing }\end{array}$ & 0.633 & 0.703 & 0.842 & & & \\
\hline $\begin{array}{l}\text { Perceived Ethical } \\
\text { Product }\end{array}$ & 0.685 & 0.785 & 0.767 & 0.837 & & \\
\hline $\begin{array}{l}\text { Perceived Ethical } \\
\text { Promotion }\end{array}$ & 0.643 & 0.830 & 0.719 & 0.811 & 0.841 & \\
\hline Perceived Value & 0.743 & 0.686 & 0.748 & 0.728 & 0.717 & 0.879 \\
\hline
\end{tabular}


Table 5 Results of Multigroup Analysis

\begin{tabular}{|c|c|c|c|c|}
\hline Paths & B & ß A & B B & $\begin{array}{l}\operatorname{MGA}(\beta \mathrm{A} \\
-\beta \mathrm{B})\end{array}$ \\
\hline Age $\rightarrow$ Intention & 0.023 & 0.014 & 0.029 & 0.014 \\
\hline Age X Perceived Value $\rightarrow$ Intention & $0.031 * *$ & 0.03 & 0.031 & 0.001 \\
\hline Frequency of Consumption $\rightarrow$ Intention & $0.283 * *$ & $0.227 * *$ & $0.330 * *$ & 0.103 \\
\hline $\begin{array}{l}\text { Frequency of consumption } \mathrm{X} \text { Perceived } \\
\text { Value } \rightarrow \text { Intention }\end{array}$ & $0.161 * *$ & $0.161 * *$ & $-0.154 * *$ & 0.008 \\
\hline Gender $\rightarrow$ Perceived Value & 0.011 & -0.016 & 0.026 & 0.042 \\
\hline $\begin{array}{l}\text { Gender X Perceived Ethical Placing } \rightarrow \\
\text { Perceived Value }\end{array}$ & $0.092 * *$ & $0.124 *$ & 0.059 & 0.065 \\
\hline $\begin{array}{l}\text { Gender X Perceived Ethical Product } \rightarrow \\
\text { Perceived Value }\end{array}$ & $-0.075^{*}$ & -0.069 & -0.075 & 0.007 \\
\hline $\begin{array}{l}\text { Perceived Ethical Placing } \rightarrow \text { Perceived } \\
\text { Value }\end{array}$ & $0.098 * *$ & 0.081 & $0.101^{*}$ & 0.020 \\
\hline Perceived Ethical Pricing $\rightarrow$ Perceived Value & $0.384 * *$ & $0.493 * *$ & $0.275 * *$ & $0.218 * *$ \\
\hline $\begin{array}{l}\text { Perceived Ethical Product } \rightarrow \text { Perceived } \\
\text { Value }\end{array}$ & $0.185 * *$ & 0.073 & $0.296^{* *}$ & 0.223 \\
\hline $\begin{array}{l}\text { Perceived Ethical Promotion } \rightarrow \text { Perceived } \\
\text { Value }\end{array}$ & $0.210 * *$ & $0.225 * *$ & $0.225^{* *}$ & 0.000 \\
\hline Perceived Value $\rightarrow$ Intention & $0.582 * *$ & $0.634 * *$ & $0.537 * *$ & $0.097 * *$ \\
\hline Perception of Healthy $\rightarrow$ Intention & -0.020 & -0.047 & 0.007 & 0.054 \\
\hline $\begin{array}{l}\text { Perception of Healthy X Perceived Value } \rightarrow \\
\text { Intention }\end{array}$ & - & - & -0.055 & 0.047 \\
\hline
\end{tabular}




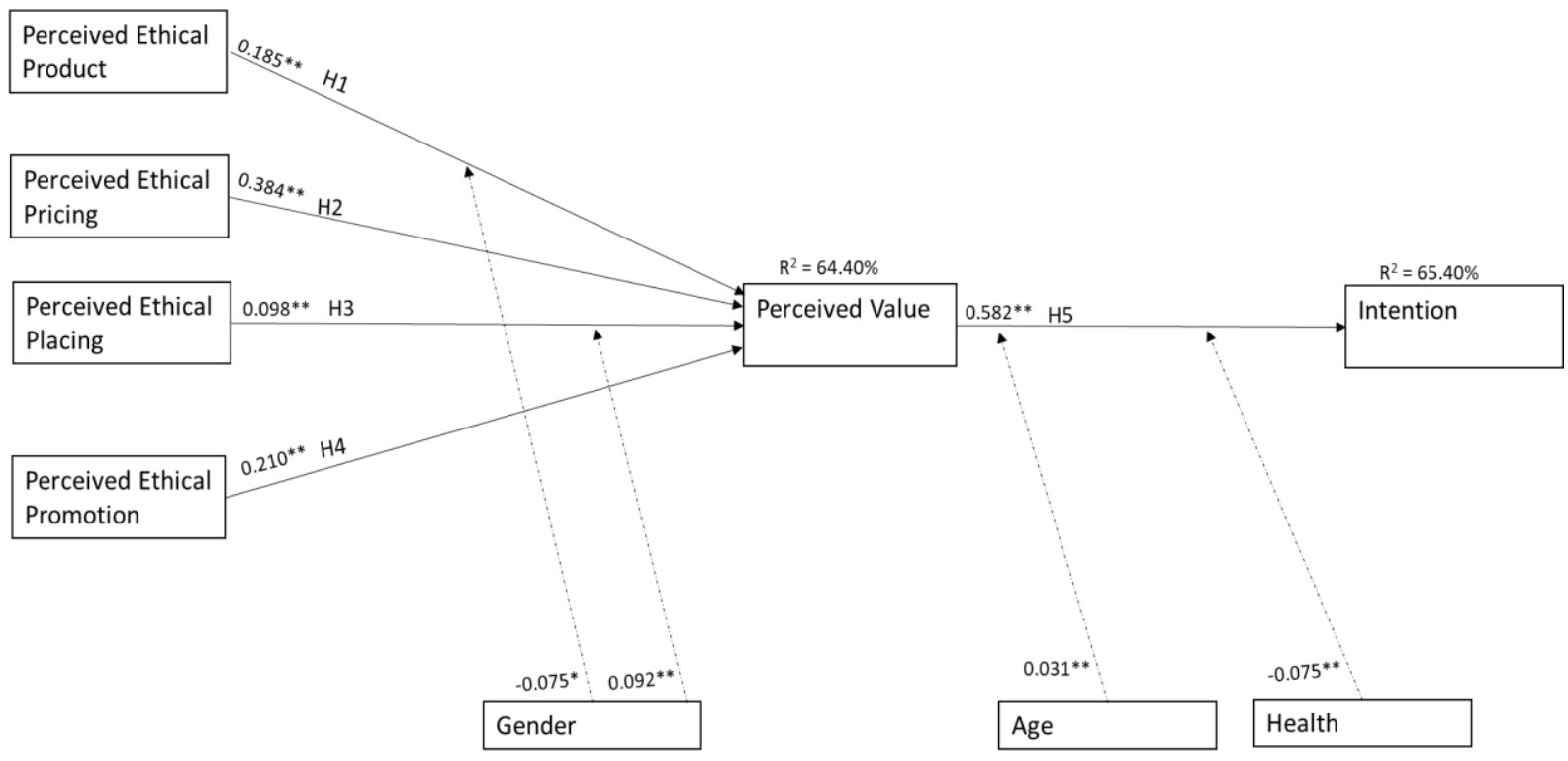

Note: ${ }^{* *} \mathrm{p}<.05 .{ }^{*} \mathrm{p}<$.1

Figure 1. Results of the proposed model 